\title{
THE EFFECT OF KNOWLEDGE ON ENTREPRENEURSHIP COMPETENCY AND STAKEHOLDER SUPPORT TO MSMES SUCCESS
}

\author{
Muliastuti Anggrahini ${ }^{* 1}$, Dudi Hendaryan² \\ Universitas Langlangbuana, Indonesia ${ }^{12}$ \\ $\underline{\text { muliastuti2909@gmail.com }}{ }^{* 1}, \underline{\text { dudihendaryan@gmail.com }}{ }^{2}$
}

\begin{abstract}
The role of Micro, Small, and Medium Enterprises (MSMEs) in the Indonesian economy has been large since the beginning. The success of MSMEs can be measured by the addition of company assets, increased profits and sales volumes, product advantages and prices, or the addition of company branches, types of products, and the number of employees. The success of MSMEs requires knowledge of entrepreneurial competence and the support of relevant stakeholders. The purpose of this research is to find out and analyze the provision of knowledge about entrepreneurship competence and stakeholder support that can support the success of MSME. This research is a descriptive and verification study with research variables that include knowledge on entrepreneurial competence and stakeholder support for the success of MSMEs. Data were analyzed using path analysis to measure the amount of contribution or influence of independent variables on the dependent variable, both direct and indirect effects through relationships with other independent variables. The analysis results showed that entrepreneurship competency knowledge ( $\mathrm{t}$-value $=2.910$ ) and support of stakeholders ( $\mathrm{t}$-value 3.658 ) have a significant impact on the MSMEs' success ( $\mathrm{f}$-value $=18.443$ ). The total effect of knowledge on entrepreneurial competence on the success of MSMEs was valued at $18.9 \%$ and the total direct and indirect influence of stakeholder support variables on the success of MSMEs was $25.1 \%$.
\end{abstract}

Keywords: Knowledge of Entrepreneurial Competence, Stakeholder Support, Entrepreneurial Competence

\section{INTRODUCTION}

MSME is a business sector that has an important role in economic growth in Indonesia. Data from BPS and the Ministry of Cooperatives in Wahyudin (2013) from all business classes shows that small businesses in Indonesia account for around $99 \%$. This means that almost all businesses in Indonesia are small businesses, with only $1 \%$ of medium and large businesses. The development and growth of MSMEs are also quite good from year to year. Almost every government emphasizes empowering MSMEs. Because this small business can be the backbone of the supply of labor, besides that large companies also emphasize the use of technology compared to human labor.

Indonesia as a developing country is very important to pay attention to the existence of MSMEs, because MSMEs have better performance in providing a productive workforce, have high productivity, and can live on the sidelines of large businesses.

Many people argue that a successful business does not require a specific recipe, but in reality, successful entrepreneurs have the same characteristics. To become a successful entrepreneur, the main requirement that must be possessed is to have an entrepreneurial spirit and character. The entrepreneurial spirit and character are influenced by skills, abilities, and competencies. Competence itself is determined by experience in entrepreneurship. Entrepreneurship is the ability to manage one's own business (Fadiati \& Purwana, 2011). Therefore the provision of knowledge and competence should be owned by an entrepreneur.

Being an entrepreneur has challenges and obstacles, and it takes effort to be able to achieve success. Also, stakeholder support such as the government, BUMN, financial or non- 
financial institutions, and NGOs is needed.

Many challenges are often faced by stakeholders, especially the government in efforts to form local entrepreneurs. Among them is the government's public policy should stimulate the development of local entrepreneurs. Because small and medium businesses play an important role in creating jobs. This small and medium business sector is always relied upon when the country is in an economic crisis. 4 things are usually of concern to the government to support the growth of the small and medium business sector, namely as follows: making rules that support the business world, tax incentive policies, direct financial assistance, and non-financial assistance.

Government regulations made must pay attention to whether the business world is possible to develop well or not. Government regulations kill small and medium businesses. The government can also make tax incentive policies by reducing or freeing tax for a certain period. The government can also prepare a place of business and provide soft credit assistance. While nonfinancial assistance can be done by accelerating business licenses.

The success of a business is essentially the success of a business achieving its goals. The success of a business may not be achieved just like that but the success of a business can be seen from the self-entrepreneur itself and other supporting factors from outside (stakeholders) that support it.

The role of Micro, Small, and Medium Enterprises (MSMEs) in the Indonesian economy has been large since the beginning. However, since the economic crisis, the role of MSMEs has increased sharply. Has been tested in several economic crises in Indonesia, the MSME sector can be a safety valve from the impact of the crisis. Although it must be acknowledged, after the economic crisis passed, MSMEs still did not experience significant policy changes.
When the economic crisis occurred, the role of MSMEs in employment was still reliable. The collapse of large industries and the formal sector, in general, makes MSMEs the most rational choice.

Constraints that become obstacles to the development of small businesses should not make small entrepreneurs feel afraid to keep on creating and innovating with their businesses. For that, they also need back-up or support from stakeholders such as the government, BUMN, financial or non-financial institutions, and NGOs.

The empowerment of small businesses should be placed on a scale of priority so that they can play a real role in improving people's lives, can anticipate environmental changes, and compete for success in the global economic race.

One type of MSME that has an unlimited target market is the t-shirt screen printing business. T-shirt screen printing business center on $\mathrm{Jl}$. $\mathrm{PHH}$. Mustofa Suci Bandung has a good existence and is not lost in the competition. This is proven by the continuous production demand starting from individual consumers who want to make unit shirts with designs that are not marketable, accept mass orders such as company uniforms, certain event committee uniforms, specific organizational uniforms and can also establish cooperation with distro business actor to supply unique t-shirt products in the trade shack they have. The tight market competition often presents an obstacle for t-shirt screen printing services.

Given the immense role of MSMEs in the economic system, it is necessary to conduct research that addresses the issue of how the influence of knowledge on entrepreneurial competencies and stakeholder support in supporting the success of MSMEs. As well as the influence of stock knowledge of entrepreneurial competence and stakeholder support that supports the 
success of MSME (Case study on screen printing business centers in the city of Bandung).

The purpose of this research is to find out and analyze the provision of knowledge about entrepreneurship competence and stakeholder support that can support the success of MSME. As well as knowing how much influence the stock of entrepreneurial competence knowledge and stakeholder support to the success of MSMEs (Case study on screen printing business centers in the city of Bandung).

So that in the end, the results of this study can be input and information about the provision of knowledge of entrepreneurial competencies and the support of any stakeholder that can support the success of the business at SMEs. And to find out how much influence the stock of entrepreneurial competence knowledge and stakeholder support to the success of SMEs (Case study on screen printing business centers in the city of Bandung). Besides being able to contribute ideas to entrepreneurs to further develop their business.

Indonesia as a developing country is very important to pay attention to the existence of MSMEs because MSMEs have better performance in providing a productive workforce, have high productivity, and can live on the sidelines of large businesses.

Many people argue that a successful business does not require a specific recipe, but in reality, successful entrepreneurs have the same characteristics. To become a successful entrepreneur, the main requirement that must be possessed is to have an entrepreneurial spirit and character. The entrepreneurial spirit and character are influenced by skills, abilities, and competencies. Competence itself is determined by experience in entrepreneurship. Provision of knowledge and competence that should be owned by an entrepreneur.

MSME is a productive business unit that stands alone, which is carried out by individuals or business entities in all economic sectors (Tambunan, 2012). In principle, the distinction between Micro, Small Business, Medium Business, and Large Businesses are generally based on the value of the initial assets (excluding land and buildings), the average annual turnover, or the number of permanent workers. To be an entrepreneur, the first thing needed is a clear idea, strong ability and commitment, capital adequacy, and sufficient energy and mind. Casson stated that the capital is not enough if it is not equipped with capabilities (Curtis, 1993): (1) Self-knowledge, which knows the business occupied; (2) Imagination, which his imagination, ideas, and perspectives; (3) Practical knowledge is having practical knowledge; (4) Search skill is the ability to find, create and imagine; (5) Foresight is far-sighted; (6) Computation skill is counting and predicting the future; (7) Communication skills, namely the ability to communicate, get along.

The obstacles that become obstacles to the development of small businesses should not make small business entrepreneurs feel afraid to go forward but keep on creating and innovating with their businesses. For that, they also need back-up or support from stakeholders such as the government, BUMN, financial or nonfinancial institutions, and NGOs. In facing various obstacles, several steps can be taken (Bangsawan, 2006): (1) Related to licensing; (2) Related to training; (3) Related to guidance and consultation; (4) Related to taxation; (5) Related to funding ; (6) Other things that need to be considered to support business development include: (a) Related agencies need to provide a database of small business development information systems, (b) Information system for credit application procedures by financial / non-financial institutions, (c) Participate in exhibitions at the regional, national, and international levels, (d) Coordinate between related institutions. 
According to Suryana (2003), a company can achieve success if three conditions are met, namely: (1) The company's objectives and policy management functions (marketing, finance, operations, and HR) must collectively show the strongest position in the market; (2) These objectives and policies are based on the strength of the company and are continuously updated (dynamically) by changing opportunities and threats to the external environment; (3) Companies must have and explore specific competencies as a driver to run the company, for example with brand reputation and low production costs.

From Suryana's statement above, it appears that one indicator to measure the success of a business is to look at the company's success in carrying out management functions, namely the functions of financial marketing, operations, and human resources. The success of the company in carrying out the functions of marketing, finance, operations, and human resources is characterized by (1) Adding company assets; (2) Increase in company profits; (3) Increased sales volume; (4) Product excellence; (5) Price advantage; (6) Add a new branch; (7) Additional types of products; (8) Increase the number of employees.

\section{METHODS}

This research is a descriptive and verification study. Descriptive research is a method that describes what is done based on the facts studied to then be processed into data and then carried out an analysis so that in the end a conclusion is generated. While verification research is a method carried out to test hypotheses using statistical calculations.

The variables used in this study are knowledge on entrepreneurial competence (independent variable (X1)), stakeholder support (independent variable (X2)), and business success (dependent variable or dependent variable $(\mathrm{Y})$ ).
Data obtained by directly visiting the t-shirt screen printing businessman at the industrial center on $\mathrm{Jl}$. $\mathrm{PHH}$. Mustofa Suci Bandung City by using questionnaires, interviews, and observations. Secondary data related to the literature is needed and is still related to the research topic as well as data regarding the number and location of t-shirt screen printing centers on $\mathrm{Jl}$. $\mathrm{PHH}$. Mustofa Suci Bandung. According to Sugiyono (2005), the population is a general area consisting of subjects or objects with certain characteristics. The population of this research is the t-shirt screen printing entrepreneurs of t-shirt screen printing centers on $\mathrm{Jl}$. $\mathrm{PHH}$. Mustofa Suci Bandung, based on the Bandung screen printing business association data.

Research data were analyzed using path analysis. Path analysis is used to measure the amount of contribution or influence of independent variables on the dependent variable, both direct and indirect effects through relationships with other independent variables. This path analysis reflects the proposed conceptual hypothesis so that it appears clear as an independent variable and as a dependent variable.

Data collection uses a structured questionnaire that has been tested for validity and reliability. In the validity test of the research instrument, the correlation number of the questions on the variables "knowledge on entrepreneurial competency", "stakeholder support" and "the success of MSME" are all above the 0.300 figure, so it is concluded that the questions in the three instruments are significant and have validity good. In the reliability test of the research instrument, it was found that the "knowledge on entrepreneurship competency" had a Cronbach alpha value of 0.952 , the "stakeholder support" variable had a Cronbach alpha value of 0.827 , and the " success of MSMEs" variable had a Cronbach alpha value of 0 ,

To make it easier to interpret the variables being studied, the 
categorization of the respondent's response score is in the form of a percentage. The principle of categorization is based on the weight of the score by finding the interval of each category based on the number of scales of the lowest and highest percentage of each variable examined. There are five categories: very low, low, medium, high, and very high (Table 1).

Table 1. Classification of Assessment Criteria

\begin{tabular}{cl}
\hline Assessment & Rating Category \\
\hline $50-90$ & Very low \\
$91-130$ & Low \\
$131-170$ & Medium \\
$171-210$ & High \\
$211-250$ & Very high \\
\hline Source: Primary Data Processing Results
\end{tabular}

(2020)

\section{RESULTS AND DISCUSSION}

The results found that the t-shirt screen printing business at the t-shirt screen printing business center $\mathrm{Jl}$. PHH. Mustofa Suci Kota Bandung is generally run by men $(68 \%)$, but some women are female (32\%). These businesses employ more than 1-4 people (81\%), and the remaining 5-19 workers (19\%). T-shirt screen printing business is run by entrepreneurs of various ages, ranges from 20 years (8\%), 21-30 years (28\%), $31-40$ years $(30 \%), 41-50$ years $(32 \%)$, and more than 50 years (2\%). Generally, the t-shirt screener has a high school education or equivalent $(66 \%)$ and starts a business at $21-30$ years old (56\%) (Table 2).

Table 2. Characteristics of Respondents by Gender

\begin{tabular}{|c|c|c|c|}
\hline & & $\mathbf{n}$ & (\%) \\
\hline \multirow[t]{2}{*}{ Gender } & Men & 34 & $68.0 \%$ \\
\hline & Woman & 16 & $32.0 \%$ \\
\hline \multirow[t]{4}{*}{ Number of workers (people) } & $1-4$ & 41 & $82.0 \%$ \\
\hline & $5-19$ & 9 & $18.0 \%$ \\
\hline & $20-99$ & 0 & $0.0 \%$ \\
\hline & $\geq 100$ & 0 & $0.0 \%$ \\
\hline \multirow[t]{5}{*}{ Age (years) } & $<20$ & 4 & $8.0 \%$ \\
\hline & $21-30$ & 14 & $28.0 \%$ \\
\hline & $31-40$ & 15 & $30.0 \%$ \\
\hline & $41-50$ & 16 & $32.0 \%$ \\
\hline & $>50$ & 1 & $2.0 \%$ \\
\hline \multirow[t]{5}{*}{ Level of education } & Middle School / equivalent & 5 & $10.0 \%$ \\
\hline & SMA / equivalent & 33 & $66.0 \%$ \\
\hline & Diploma & 6 & $12.0 \%$ \\
\hline & Bachelor degree) & 6 & $12.0 \%$ \\
\hline & Postgraduate (S2) & 0 & $0.0 \%$ \\
\hline \multirow{5}{*}{$\begin{array}{l}\text { Characteristics } \\
\text { Respondents by Age at } \\
\text { Starting a Business (years) }\end{array}$} & $<20$ & 15 & $30.0 \%$ \\
\hline & $21-30$ & 28 & $56.0 \%$ \\
\hline & $31-40$ & 7 & $14.0 \%$ \\
\hline & $41-50$ & 0 & $0.0 \%$ \\
\hline & $>50$ & 0 & $0.0 \%$ \\
\hline \multicolumn{2}{|l|}{ Total } & 50 & $100.0 \%$ \\
\hline
\end{tabular}

Source: Primary Data Processing Results (2020) 
Based on table 3, it can be seen that the responses of respondents based on the dimensions of the knowledge on entrepreneurship competencies gained values ranging from 157.75-187.75. The highest dimension value on the dimension of self-knowledge is equal to 187.75 (high category), while the lowest dimension value on the dimension of computation skills is 177.5 (high category). The overall value of the knowledge on the entrepreneurship competency score is 181,12 or categorized as high (171210).

\section{Table 3. Total Distribution of Valuation on Knowledge on Entrepreneurship Competencies}

\begin{tabular}{|c|c|c|c|c|}
\hline \multirow{2}{*}{$\begin{array}{l}\text { Dimension } \\
\text { Self- } \\
\text { Knowledge }\end{array}$} & \multicolumn{2}{|r|}{ Statement } & \multirow{2}{*}{$\begin{array}{r}\begin{array}{r}\text { Total } \\
\text { score }\end{array} \\
212\end{array}$} & \multirow{2}{*}{$\begin{array}{l}\text { Category } \\
\text { Very high }\end{array}$} \\
\hline & $\mathrm{X} 1.1$ & I am at the level of technical & & \\
\hline & $\mathrm{X} 1.2$ & $\begin{array}{l}\text { I am at the level of marketing } \\
\text { competence }\end{array}$ & 170 & Medium \\
\hline & $\mathrm{X} 1.3$ & $\begin{array}{l}\text { I am at the level of Financial } \\
\text { Competence }\end{array}$ & 164 & Medium \\
\hline & $\mathrm{X} 1.4$ & $\begin{array}{l}\text { I am at the level of Human Relationship } \\
\text { Competence Ability }\end{array}$ & 205 & High \\
\hline \multicolumn{3}{|c|}{ Overall Average Value of Self Knowledge Dimensions } & 187.75 & High \\
\hline \multirow[t]{4}{*}{ Imagination } & $\mathrm{X} 1.5$ & $\begin{array}{l}\text { I am at the level of Ability to Have a New } \\
\text { Idea }\end{array}$ & 166 & Medium \\
\hline & $\mathrm{X} 1.6$ & I Have a Perspective Skill Level & 130 & Low \\
\hline & $\mathrm{X} 1.7$ & $\begin{array}{l}\text { I Have the Ability to Not Rely on Past } \\
\text { Successes }\end{array}$ & 168 & Medium \\
\hline & $\mathrm{X} 1.8$ & I have a level of imagination & 167 & Medium \\
\hline \multicolumn{3}{|c|}{ Overall Average Value of Imagination Dimensions } & 157.75 & Medium \\
\hline \multirow[t]{6}{*}{$\begin{array}{l}\text { Practical } \\
\text { Knowledge }\end{array}$} & $\mathrm{X} 1.9$ & $\begin{array}{l}\text { I Have a Level of Ability in Engineering } \\
\text { Knowledge }\end{array}$ & 214 & Very high \\
\hline & $\mathrm{X} 1.10$ & $\begin{array}{l}\text { I Have a Level of Ability in Designing } \\
\text { Products }\end{array}$ & 189 & High \\
\hline & $\mathrm{X} 1.11$ & $\begin{array}{l}\text { I Have a Level of Ability in Designing } \\
\text { Products }\end{array}$ & 214 & Very high \\
\hline & $\mathrm{X} 1.12$ & I Have an Ability Level in Bookkeeping & 169 & Medium \\
\hline & $\mathrm{X} 1.13$ & $\begin{array}{l}\text { I Have a Level of Ability in } \\
\text { Administration }\end{array}$ & 166 & Medium \\
\hline & $\mathrm{X} 1.14$ & I have a level of ability in marketing & 188 & High \\
\hline \multicolumn{3}{|c|}{ Overall Average Practical Knowledge Dimensions } & 190 & High \\
\hline \multirow[t]{3}{*}{ Search Skill } & $\mathrm{X} 1.15$ & I have the ability to find a problem & 168 & Medium \\
\hline & $\mathrm{X} 1.16$ & I have the ability to be creative & 179 & High \\
\hline & $\mathrm{X} 1.17$ & I have the ability to imagine & 188 & High \\
\hline \multicolumn{3}{|c|}{ Overall Average Value of Search Skill Dimensions } & 178.33 & High \\
\hline \multirow[t]{2}{*}{ Foresight } & $\mathrm{X} 1.18$ & I have the ability to look far ahead & 166 & Medium \\
\hline & $\mathrm{X} 1.19$ & I have the ability to do something & 191 & High \\
\hline \multicolumn{3}{|c|}{ Overall Average Foresight Dimension } & 178.5 & High \\
\hline & $\mathrm{X} 1.20$ & I have the ability to communicate & 200 & High \\
\hline
\end{tabular}




\begin{tabular}{lllrl}
\hline Communicatio & X1.21 & I have the ability to connect with others & 195 & High \\
n Skill & X1.22 & I Have the Ability to Associate & 199 & High \\
Overall Average & Value of Communication Skill Dimensions & 198 & High \\
Computation & X1.23 I have the ability to count & 191 & High \\
Skill & X1.24 & I Have the Ability to Predict the Future & 164 & Medium \\
Overall Average Value of Computation Skill Dimensions & 177.5 & High \\
$\begin{array}{l}\text { Overall Average Value Stock Variable Knowledge Entrepreneurship } \\
\text { Competence }\end{array}$ & 181.12 & High \\
\hline
\end{tabular}

Source: Primary Data Processing Results (2020)

$\begin{array}{rcc}\text { Based on table } 4 \text {, the } & \text { on } \\ \text { respondents' } & \text { responses to the }\end{array}$ stakeholder support variables obtained values ranging from 147-216. With the highest indicator score at X2.1 "the level of convenience in terms of bureaucracy and licensing" is equal to 216 (very high category). While the lowest indicator at
X2.4 "the level of provision of credit fund allocations" and X2.5 "Increasing interagency coordination" is respectively 147 (medium category). The overall value of the stakeholder support variable scored 171 so it is categorized as high (171210).

Table 4. Distribution of Assessments on Stakeholder Support Variables

\begin{tabular}{llcc}
\hline & \multicolumn{1}{c}{ Statement } & $\begin{array}{c}\text { Total } \\
\text { score }\end{array}$ & Category \\
\hline X2.1 & Ease of Level in Bureaucracy and Licensing & 216 & Very high \\
X2.2 & Level of Ease in Following Training & 178 & High \\
X2.3 & Level of Coaching and Guidance in the Field of & 179 & High \\
& Management Consultation & & Medium \\
X2.4 & Level of Provision of Credit Fund Allocation & 147 & Medium \\
X2.5 & Improved Coordination among Institutions & 147 & High \\
X2.6 & Increased Market Access & 172 & Medium \\
X2.7 & Income Tax Imposition Rate & 153 & High \\
X2.8 & Improved Information Systems Development & 176 & High \\
Overall Average Value of Stakeholder Support Variables & 171 & \\
\hline
\end{tabular}

Source: Primary Data Processing Results (2020)

Table 5 shows the respondents' responses based on the dimensions of the success of the MSME variable obtaining values ranging from 156196.5. The highest dimension value in the dimensions of the marketing field is equal to 196.5 (high category), while the lowest dimension value in the dimensions of the human resource field is 156 (medium category). The overall value of the MSME business success variable scored 174.5 and was categorized as high category (171-210).

The inferential analysis method used in this study is path analysis. Path analysis is used to find the influence of independent variables on the bound directly or indirectly. Before conducting a path analysis, first of all, a classical assumption test will be calculated with the aim that the resulting equation is good and unbiased. 
Table 5. Distribution of Valuations on the Variables of The Success of MSMEs

\begin{tabular}{|c|c|c|c|c|}
\hline Dimension & & Statement & Total score & Category \\
\hline \multirow[t]{3}{*}{ Finance Sector } & Y1 & Ability to Add Company Assets & 164 & Medium \\
\hline & Y2 & Ability to Increase Company Profit & 172 & High \\
\hline & Y3 & Ability to Increase Sales Volume & 176 & High \\
\hline \multicolumn{3}{|c|}{ Overall Average Dimensions of Financial Fields } & 171 & High \\
\hline \multirow[t]{4}{*}{ Marketing } & Y4 & $\begin{array}{l}\text { Ability In Offering The Advantages Of } \\
\text { Products Offered }\end{array}$ & 212 & Very high \\
\hline & Y5 & Ability To Determine Competitive Prices & 214 & Very high \\
\hline & Y6 & $\begin{array}{l}\text { Ability In Adding The Types Of Products } \\
\text { Offered }\end{array}$ & 213 & Very high \\
\hline & Y7 & Ability to Add New Branches & 147 & Medium \\
\hline \multicolumn{3}{|c|}{ Overall Average Value of Stakeholder Support Variables } & 196.5 & High \\
\hline $\begin{array}{l}\text { Human } \\
\text { Resources Sector } \\
\text { Overall }\end{array}$ & Y8 & $\begin{array}{l}\text { Ability to Increase the Number of } \\
\text { Employees } \\
\text { Value of Marketing Dimensions }\end{array}$ & 156 & Medium \\
\hline \multicolumn{3}{|c|}{ Overall Average Values of MSME Business Success Variables } & 174.5 & High \\
\hline
\end{tabular}

Source: Primary Data Processing Results (2020)

The classic assumption tests used are the normality test, multicollinearity test, and heteroscedasticity test. Normality test to test whether, in a regression model, the dependent variable, the independent variable, or both have normal distribution or not using the Kolmogorov-Smirnov test and the significance value is above 0.05 . Based on table 6 it can be seen that the significance value is above 0.05 which is equal to 0.200 . So that it can be said that the regression model has a normal distribution.

Table 6. Data Normality Test

\begin{tabular}{lll}
\hline One-Sample Kolmogorov-Smirnov Test & $\begin{array}{c}\text { Unstandardized } \\
\text { Residual }\end{array}$ \\
\hline N & & 50 \\
Normal Parameters & a, b & 0000000 \\
Most Extreme Differences & The mean &, 44117311 \\
& Std. Deviation &, 076 \\
& Absolute &, 076 \\
Statistical Test & Positive &,- 058 \\
Asymp. Sig. (2-tailed) & Negative &, 076 \\
a. Test distribution is Normal. &, $200^{c, d}$ \\
b. Calculated from data. & \\
c. Lilliefors Significance Correction. & \\
d. This is a lower bound of true significance. & \\
\hline
\end{tabular}

Source: Primary Data Processing Results (2020)

Multicollinearity Testing aims to test whether the regression model found a correlation between independent variables. A good regression model should not occur in the correlation between independent variables. A good regression model should not occur in the correlation between independent variables.

If in the regression model formed there is a high or perfect correlation between the independent variables, then the regression model is stated to contain multicollinear symptoms. 
Multicollinearity test using TOL (tolerance) and variance inflation factor (VIF) statistics according to Suliyanto (2011) multicollinearity test by looking at TOL (tolerance) and variance inflation factor (VIF) of each independent variable on the dependent variable. If the VIF value is not more than 10 , then the model is declared to have no symptoms of multicollinearity.

Table 7. Multicollinearity Test Table

\begin{tabular}{cccc}
\hline Coefficients $^{\mathbf{a}}$ Model & & \multicolumn{2}{c}{ Collinearity Statistics } \\
& & Tolerance & VIF \\
\hline 1 & X1 & 0.816 & 1,225 \\
& X2 & 0.816 & 1,225 \\
a. Dependent Variable: Y & &
\end{tabular}

Source: Primary Data Processing Results (2020)

In the table above it can be seen that the tolerance value is above 0.10 and the VIF value is below 10. So it can be concluded that there is no multicollinearity problem in the regression model.

The heteroscedasticity test aims to test whether in the regression model there

is an inequality of variance from residuals to observations or another. If the variance of residuals from one observation to another observation is still called homoscedasticity, whereas if it is different is called heteroscedasticity. A good regression model does not have a heteroscedasticity problem.

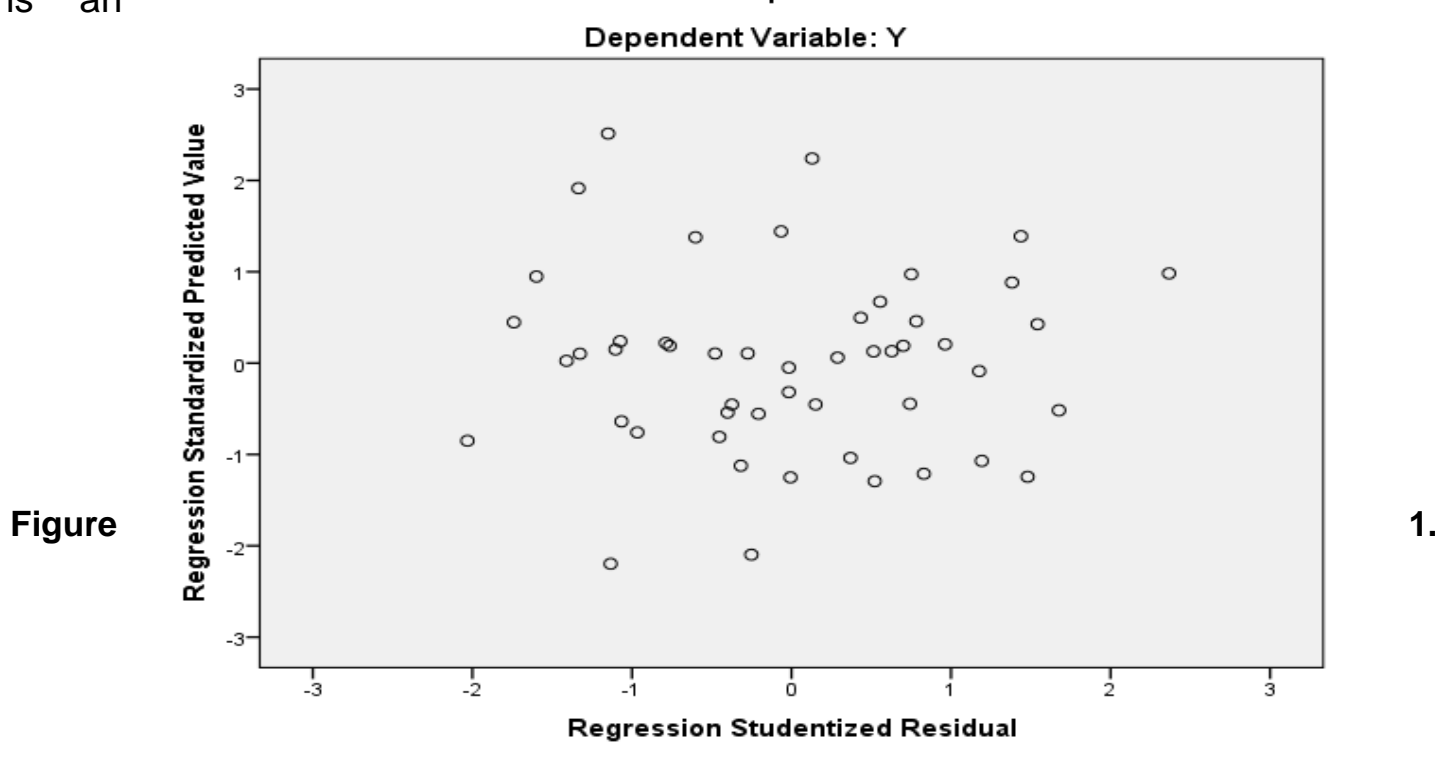

\section{Heteroscedasticity Test \\ Source: Primary data processed (2020)}

One way to find out whether there is heteroscedasticity in a multiple linear regression model is to look at the scatter plot graph or the predictive value of the dependent variable that is SRESID with residual error, namely ZPRED. If there is no specific pattern and it does not spread above and below the zero on the $y$ axis, then heteroscedasticity does not occur. A good model is one that does not occur heteroscedasticity (Ghozali, 
2016). The results of heteroscedasticity testing are as follows.

Based on the results of heteroscedasticity testing using scatter plots, it can be seen that the points are above and below zero. So it can be concluded that there is no heteroscedasticity problem in the regression model. All classic assumption tests have been fulfilled so that multiple regression analysis can proceed because it has been found that there is no violation of the classical assumptions.
After the classical assumption test requirements are met, path analysis can be performed to find the contribution or influence of the independent variable on the dependent variable, both the direct effect and the indirect effect through relationships with other independent variables.

In the path analysis method, to look for causal relationships or the influence of research variables, the correlation matrix of the knowledge on entrepreneurial competency (X1) and stakeholder support (X2) is calculated first.

Table 8. Correlation Coefficient Between Variables

\begin{tabular}{|c|c|c|c|c|}
\hline \multicolumn{2}{|c|}{ Correlations } & $\mathbf{X 1}$ & $\mathrm{X} 2$ & $\mathbf{Y}$ \\
\hline \multirow[t]{3}{*}{$\mathrm{X} 1$} & Pearson Correlation & 1 & $0.429^{* *}$ & $0.537^{\star \star}$ \\
\hline & Sig. (2-tailed) & & 0.002 & 0,000 \\
\hline & $\mathrm{N}$ & 50 & 50 & 50 \\
\hline \multirow[t]{3}{*}{ X2 } & Pearson Correlation & 0.429 ** & 1 & 0.582 ** \\
\hline & Sig. (2-tailed) & 0.002 & & .000 \\
\hline & $\mathrm{N}$ & 50 & 50 & 50 \\
\hline \multirow[t]{3}{*}{ Y } & Pearson Correlation & $0.537^{* *}$ & $0.582^{* *}$ & 1 \\
\hline & Sig. (2-tailed) & 0,000 & 0,000 & \\
\hline & $\mathrm{N}$ & 50 & 50 & 50 \\
\hline
\end{tabular}

Source: Primary Data Processing Results (2020)

Correlation tables are used to determine the relationship between independent variables and between independent and dependent variables. Based on the table shows that the relationship between $X 1$ and $X 2$ is 0.429 with a positive relationship direction. This indicates that there is a positive relationship between the knowledge of entrepreneurial competence with the support of stakeholders with the strength of a fairly close relationship. The relationship between $X 1$ and $Y$ is 0.537 and the relationship between $X 2$ and $Y$ is 0.582 with the strength of a fairly close relationship. After the relationship between variables is known, then the next is to make a recapitulation for the magnitude of the path coefficient on each variable and the magnitude of the effect together.

Table 9. The magnitude of the Path coefficient

\begin{tabular}{lccc}
\hline \multicolumn{1}{c}{ Variable } & $\begin{array}{c}\text { Path } \\
\text { coefficient }\end{array}$ & $\begin{array}{c}\text { Simultaneous } \\
\text { Influence }\end{array}$ & $\begin{array}{c}\text { Effect of } \\
\text { Residue }\end{array}$ \\
\hline Knowledge of entrepreneurial & Pyx1 & 0.440 & 0.560 \\
competency knowledge (X1) & 0.352 & & \\
Stakeholders Support (X2) & Pyx2 $=$ & & \\
& 0.431 & & \\
\hline
\end{tabular}

Source: Primary Data Processing Results (2020) 
Where :

$Y \quad=$ success of SMEs

$\mathrm{X} 1=$ knowledge of entrepreneurship competence

$\mathrm{X} 2$ = stakeholders support

By observing the table above, the path equation is obtained as follows:

\section{$Y=.352 X 1+0.431 X 2+\varepsilon 1$}

Value of the variable path coefficient stakeholders supports greater than the variable path coefficient armed with knowledge on entrepreneurial competence that means stakeholders support more decisive (greater effect) on the success of MSMEs compared armed with the knowledge of entrepreneurial competence both directly and indirectly.

The regression coefficient sign of the independent variable shows the direction of the relationship of the variable concerned with the success of MSMEs. The regression coefficient for the independent variable $\mathrm{X} 1$ is positive, indicating a direct relationship between the knowledge of entrepreneurship competency (X1) with the success of MSMEs (Y). The regression coefficient of variable $\mathrm{X} 1$ of 0.352 implies that for each increase of knowledge on entrepreneurship competency knowledge (X1) of one unit will cause an increase in the success of MSMEs $(Y)$ of 0.352 units.

The regression coefficient for the independent variable $\mathrm{X} 2$ is positive, indicating a direct relationship between stakeholders' support (x2) and the success of MSMEs ( $\mathrm{Y}$ ). The regression coefficient of variable X2 of 0.431 implies that each increase in Support of Stakeholders (X2) of one unit will cause an increase in the success of MSMEs $(Y)$ of 0.431 units.

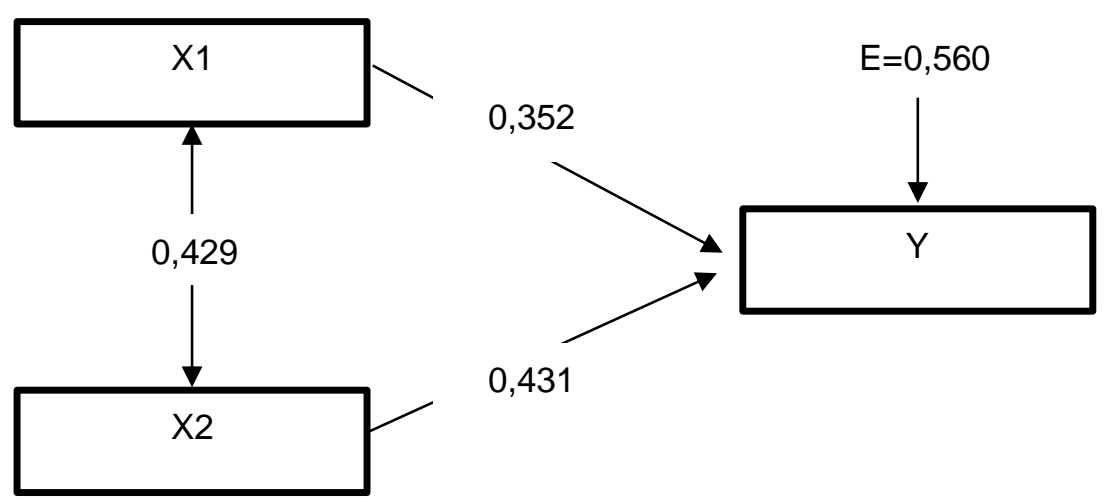

Figure 2. Path Model

Source: Primary Data Processing Results (2020)

The influence together (coefficient of determination) is obtained at 0.440 or $44.0 \%$. This means that the knowledge of entrepreneurial competence and support of stakeholders gives an influence on the success of MSMEs of $44.0 \%$, while the remaining $56.0 \%$ can be explained by other variables not examined. Figure 2 shows a picture of the influence between the knowledge on entrepreneurial competence (X1) and Stakeholder support (X2) on the Success of SMEs $(Y)$.
After a path analysis is done, then hypothesis testing can be done. This study using a partial hypothesis test (ttest) and simultaneous hypothesis testing ( $\mathrm{F}$ test). Referring to table 9, it can be seen that the direction of the knowledge on entrepreneurship competency with the success of MSMEs is positive (note the coefficient of the knowledge on entrepreneurial competency in column B), there is written 0.352 . It means that when there is an increase in knowledge of 
entrepreneurial competency, it will increase the success of MSMEs. Then testing the hypothesis using the t-test has the following conditions: (1) If $t$ value $>\mathrm{T}$ table then $\mathrm{H}_{0}$ is in the rejection area, meaning $\mathrm{Ha}$ is accepted or there is an influence; (2) If $t$ value $<t$ table then $\mathrm{H}_{0}$ is in the receiving area, meaning $\mathrm{Ha}$ is rejected or there is no influence.

\section{Hypothesis 1:}

$\mathrm{H}_{0} 1$ : There is no significant influence of knowledge on entrepreneurship competence on the success of MSMEs. $\mathrm{H}_{\mathrm{a}}$ 1: There is a significant influence of knowledge on entrepreneurship competence on the success of MSMEs. Based on the provisions previously stated, where t-value of 2.910 is obtained and the degree of freedom (nk-1) or 50-2-1 = 47 the t-table of 2,012 is obtained, so t-value $>$ t-table. It means $\mathrm{H}_{0}$ rejected and $\mathrm{H}_{\mathrm{a}}$ accepted, then there is a significant influence between the knowledge on entrepreneurship competence on the success of MSMEs. Thus the hypothesis which states that there is an influence between the knowledge on entrepreneurship competence on the success of MSMEs can be accepted. (Hypothesis 1 is accepted)

Furthermore, again referring to table 9 , it can be seen that the direction of the relationship between Stakeholders Support with the Success of MSMEs is positive (note the value of the stakeholders' support coefficient in column B), there is written 0.431 meaning that when there is an increase in stakeholder support it will increase the success of MSMEs.

Then testing the hypothesis using the ttest has the following conditions: (1) If $t$ value $>T$ table then $\mathrm{H}_{0}$ is in the rejection area, meaning $\mathrm{Ha}$ is accepted or there is an influence; (2) If $t$ value $<t$ table then $\mathrm{H}_{0}$ is in the receiving area, meaning $\mathrm{Ha}$ is rejected or there is no influence.

\section{Hypothesis 2:}

$\mathrm{H}_{0} 2$ : There is no significant influence of support stakeholders on the success of MSMEs

$\mathrm{H}_{\mathrm{a}} 2$ : There is a significant influence of stakeholders support on the success of MSMEs

Based on the provisions previously stated, in which the t-test obtained was 3.658 and the degree of freedom (nk-1) or 50-2-1 = 47 obtained the $t$ table of 2.012 so that $t$-value $>t-$ table. This means that $H_{0}$ is rejected and $\mathrm{H}_{\mathrm{a}}$ is accepted, then there is a significant influence between stakeholder support on the success of MSMEs. Thus, the hypothesis which states that there is an influence between stakeholder support on the success of MSMEs can be accepted. (Hypothesis 2 is accepted).

Based on the results of calculations using SPSS 23.0, to find out whether the knowledge on entrepreneurship competency and stakeholder support concomitantly affects the success of MSMEs. Table 10 shows the technique to get the calculation results using the $F$ test.

Table 10. Simultaneous Test

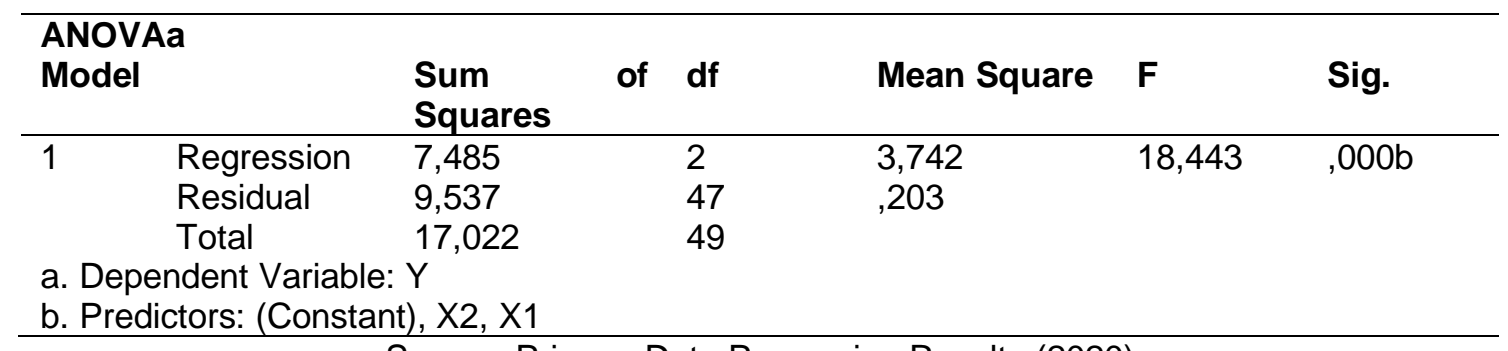

Source: Primary Data Processing Results (2020) 
From table 10, it is known that the F-value is 18.444 and then the significance value (sig.0,000). When compared between the significance value (sig) with alpha value $(\alpha=0.05)$, the significance value is smaller than the alpha value, meaning that the knowledge on entrepreneurship competence and support of stakeholders to the success of MSMEs has a significant effect. Then the authors conducted a hypothesis test with the $\mathrm{F}$ test, with the following conditions: (1) If $\mathrm{F}$-value $>\mathrm{F}$-table, $\mathrm{H}_{0}$ is rejected and $\mathrm{Ha}$ is accepted, which means that there is a significant influence between the knowledge on entrepreneurship competence and support of stakeholders on the success of MSMEs. (2) If $\mathrm{F}$-value $<\mathrm{F}$-table, $\mathrm{H}_{0}$ is rejected and $\mathrm{Ha}$ is rejected, which means that there is no significant influence between the knowledge on entrepreneurship competence and support of stakeholders on the success of MSMEs.

\section{Hypothesis 3:}

$\mathrm{H}_{0} 3$ : There is no significant influence of knowledge on entrepreneurship competence and stakeholders support on the success of MSMEs

$\mathrm{H}_{\mathrm{a}} 3$ : There is a significant influence of knowledge on entrepreneurship competence and stakeholder support on the success of MSMEs.

Table 11. Coefficient of Determination

\begin{tabular}{|c|c|c|c|c|c|c|}
\hline \multirow{2}{*}{$\begin{array}{c}\text { Variabl } \\
\text { e }\end{array}$} & \multirow{2}{*}{$\begin{array}{c}\text { Path } \\
\text { Coefficie } \\
\text { nt }\end{array}$} & \multirow[t]{2}{*}{ Direct } & \multicolumn{2}{|c|}{ Indirect } & \multirow{2}{*}{$\begin{array}{c}\text { Total } \\
\text { Influence }\end{array}$} & \multirow{2}{*}{$\begin{array}{c}\text { Total Influence } \\
\text { (\%) }\end{array}$} \\
\hline & & & $\mathrm{X} 1$ & X2 & & \\
\hline $\mathrm{X} 1$ & 0,352 & 0,124 & & 0,065 & 0,189 & $18,9 \%$ \\
\hline $\mathrm{X} 2$ & 0,431 & 0,186 & 0,065 & & 0,251 & $25,1 \%$ \\
\hline \multicolumn{5}{|c|}{ Coefficient of Determination (R2) } & $0 ., 40$ & $44,0 \%$ \\
\hline
\end{tabular}

Source: Primary Data Processing Results (2020)

Based on the provisions stated above, where F-value is 18.444 and free degrees (nk-1) or 50-2-1 = 47, F-table figures are 3.195 while $F$-value is 18.444 so $F$-value> $F$-table means that $\mathrm{H}_{0}$ is rejected and $\mathrm{H}_{\mathrm{a}}$ is accepted, it means there is a significant influence between the knowledge on entrepreneurship competence and stakeholder support for the success of MSME.

Table 11 displays the results of the calculation of the magnitude of the direct and indirect effects of each independent variable on the dependent variable.

The table shows that the total influence of the knowledge on entrepreneurship competence on the success of MSMEs is worth $18.9 \%$ and the total direct and indirect influence of the stakeholder's support variable on the success of MSMEs is $25.1 \%$. If these two numbers are added together, they will be equal to the coefficient of determination. Thus it means that the contribution of stakeholder support is greater than the provision of knowledge of entrepreneurial competencies.

\section{CONCLUSION}

From the research results described above, the following conclusions are that respondents' responses regarding the variables of this study belong to the high category with an average value on the knowledge on entrepreneurial competency, stakeholder support, and the success of MSME were high. There is also a positive relationship between the knowledge of entrepreneurship competencies and the support of stakeholders where the strength of the relation is sufficiently close. Knowledge of entrepreneurship competencies and the support of stakeholders give an impact on the success of MSMEs.

The research also found that the knowledge on entrepreneurship 
competencies and support of stakeholders has a significant effect on the success of MSMEs, respectively, and both concomitantly impact the success of MSMEs. The contribution of stakeholder support is greater than the knowledge of entrepreneurial competencies.

\section{REFERENCES}

Bangsawan, Satria. (2006). Manajemen Pemasaran Usaha Kecil: Kasus Industri Pengolahan Makanan dan Ritel. Jakarta: Graha IImu.

Curtis, Dan B. (1993). Komunikasi Bisnis dan Profesional. Bandung: Remaja Rosdakarya

Fadiati, Ari \& Purwana, Dedi. (2011). Menjadi Wirausaha Sukses. Bandung : Remaja Rosdakarya.

Ghozali, Imam. (2016). Aplikasi Analisis Multivariate dengan Program IBM
SPSS 23. Edisi 8. Semarang: Badan Penerbit Universitas Dipenogoro.

Sugiyono. (2005). Metode Penelitian Kuantitatif, Kualitatif dan R\&D. Bandung: Alfabeta

Suliyanto. (2011). Ekonometrika Terapan: Teori dan Aplikasi dengan SPSS. Tangerang: Teras IImu.

Suryana. (2003). Kewirausahaan. Pedoman Praktis, Kilat dan Proses Menuju Sukses. Jakarta: PT Salemba Empat.

Tambunan, T. (2012). Usaha Mikro Kecil dan Menengah di Indonesia: IsuIsu Penting. Jakarta: LP3ES

Wahyudin, Dian. (2013). Peluang atau Tantangan Indonesia Menuju ASEAN Economic Community 2015. Semarang: Lembaga Penerbit Universitas Diponegoro. 